\title{
DESIGNING SELF-REGULATED LANGUAGE LEARNING STRATEGY INSTRUCTIONAL PROGRAM IN A BLENDED LEARNING ENVIRONMENT FOR PRE-SERVICE TEACHERS IN CHINA
}

\author{
Aminah Ma Ping1, \\ Qiao Hong'i \\ ${ }^{1}$ Faculty of Foreign Language Studies, \\ Shaanxi Normal University, \\ P. R. of China \\ ${ }^{2}$ Faculty of Foreign Languages, \\ Xin Jiang Institute of Education, \\ P. R. of China
}

\begin{abstract}
:
Self-Regulated Learning (SRL) is considered a useful framework for strategy instruction. Teachers play a key role in designing and implementing strategy instruction; however, strategy instruction in teacher preparation program has been given less concern. Factors such as curriculum constraints, transmissive style of teaching strategies in the classroom etc. put strategy instruction in teacher education in a rather difficult position. Thus, with theoretical basis of SRL, this study proposes an alternative approach of strategy instruction in a blended learning environment to offer some insights into a strategy instructional program for teacher training. It is expected to provide an experiential and active learning experience for pre-service teachers to promote their own use of strategies in language learning as well as their knowledge of learning strategy and strategy instruction. The current article presents the results of needs analysis and describes the program's theoretical foundation, design guidelines and outlines the program structure.
\end{abstract}

Keywords: self-regulated learning; blended learning; strategy instruction; pre-service teachers

\section{Introduction}

Self-Regulated Learning (SRL), a multidimensional construct in educational psychology, has exerted a strong influence on the research in learning strategies ( $\mathrm{Hu}, 2007)$. It has repeatedly proved that SRL can be a useful framework for strategy instruction to empower students' strategy use, strategy awareness and academic achievement

\footnotetext{
${ }^{i}$ Correspondence: email maping2012@snnu.edu.cn, enjoy1208@163.com
} 
(Butler,1998; Zimmerman, 2000; Weinstein, Husman \& Dierking, 2005). In comparison with the traditional face-to-face strategy instruction in the classroom, the potentials of online learning environment in supporting self-regulated learning and strategy instruction have been investigated and advocated by some researchers (e.g., Dabbagh \& Kitsantas, 2005). Bellhauser, Losch, Winter and Schmitz (2016) investigated a web-based training to foster the development of self-regulated learning strategies among university students, and the findings suggested that a combination of online training with traditional face-to-face strategy instruction in a blended learning environment may provide a better alternative solution to conduct strategy instruction in a more effective and efficient way.

Preparing strategic and self-regulated learners has been a major concern in educational reform around the world. Teachers play a key role in developing learners' use of strategies in language learning. However, the findings of several studies (e.g., Elen \& Lowyck, 1999; Van Deur, Napier \& Lawson, 2016) indicate that pre-service teachers lack in strategic knowledge, especially metacognitive and motivational strategies, and it suggests that it is necessary to provide strategy training for pre-service teachers. Learning strategies, to cultivate students' competence of learning how to learn has been stated as one of the educational objectives in the national curriculum standards since 2001 in China. Recent studies (Du, Jiao \& Zhen, 2011) investigating teachers' beliefs and implementation of strategy instruction indicated that majority of teachers are ill-informed about learning strategies and cannot perform strategy instruction successfully in class. Vieira's analysis (2003) showed that the key factors that affect implementation of strategy instruction are curriculum constraints, teacher beliefs and teachers' lack of knowledge and skills about strategy and strategy instruction. Thus, it is important to improve teachers' strategic knowledge and skills in strategy instruction.

Pre-service teacher training is considered a critical stage for teachers' professional development. However, strategy and strategy instruction are usually not emphasized in the teacher preparation programs considering time constraints and the emphasis on teachers' pedagogical and subject content knowledge development (Rubin, Chamot, Harris \& Anderson, 2007). So far, there has been few programs to provide a systematic way to enhance student teachers' knowledge about learner strategy and strategy instruction; besides, learning strategy and strategy instruction are merely taught in a transmissive way as part of pedagogical knowledge and skills to memorize rather than engage student teachers in an active and experiential way of learning. Thus, with theoretical basis of self-regulated learning theory and language learning strategies, this discrepancy inspired us to propose an alternative approach of strategy instruction in a blended learning environment to offer some insights into the strategy instructional program for teacher training. 


\section{Context}

The study focuses on 77 second-year students intending to be English language teachers, who are required to take four-year teacher training programs at Shaanxi Normal University, China. These student teachers are expected to be equipped with sufficient language knowledge and skills as well as pedagogical knowledge for their teaching professional growth. This study attempts to develop a Self-Regulated Language Learning Strategy (SRLLS) instructional program for these student teachers to promote their own use of strategies in language learning as well as their knowledge of learning strategy and strategy instruction. In the present article, the program's theoretical foundation, design guidelines, and the structure of the instructional modules will be outlined. It begins with an analysis of the student teachers' beliefs on learning strategy and instruction and their problems and difficulties in learning English.

\section{Needs analysis}

Total 77 student teachers in second year teacher preparation programs voluntarily participated in the study. Their needs in terms of strategy and strategy instruction were identified from the two aspects: one is student teachers' views about the difficulties and problems they have in learning language skills and knowledge; another is their perceptions of learning strategy and strategy instruction in EFL classroom.

Frist, Analysis of the difficulties in language skills and knowledge. The participants were required to fill up a questionnaire about their views of their abilities in terms of language knowledge and skills. Both qualitative and quantitative data were analysed. The results showed that majority of the respondents believe that their abilities of learning language knowledge and skills are average or below average levels (see table 1). Besides, the qualitative data were coded and analyzed to identify the major difficulties and problems they have in terms of learning language knowledge and skills, which are further used as references for the selection of strategies covered in the instructional content. For example, the difficulties in learning vocabulary mentioned by the respondents are the following five aspects, that is, memorizing, insufficient vocabulary size level, word spelling, word usage, distinguishing synonyms, derivatives etc.

Table 1: Student teachers' views about their abilities in learning English

\begin{tabular}{|l|c|c|c|c|}
\hline & Very good & Good & Quite good & Not good \\
\hline Grammar & $0.66 \%$ & $10.53 \%$ & $69.08 \%$ & $19.74 \%$ \\
\hline Pronunciation & 0 & $17.11 \%$ & $67.76 \%$ & $15.13 \%$ \\
\hline Vocabulary & 0 & $9.21 \%$ & $68.42 \%$ & $22.37 \%$ \\
\hline Listening & 0 & $9.21 \%$ & $67.74 \%$ & $20.39 \%$ \\
\hline Speaking & $0.66 \%$ & $9.21 \%$ & $65.13 \%$ & $25 \%$ \\
\hline Reading & $0.66 \%$ & $25.66 \%$ & $69.08 \%$ & $4.61 \%$ \\
\hline Writing & 0 & $9.21 \%$ & $73.68 \%$ & $17.11 \%$ \\
\hline
\end{tabular}


DESIGNING SELF-REGULATED LANGUAGE LEARNING STRATEGY INSTRUCTIONAL PROGRAM IN A BLENDED LEARNING ENVIRONMENT FOR PRE-SERVICE TEACHERS IN CHINA

Second, student teachers' beliefs about learning strategy and strategy instruction. Total 11 items were selected and modified based on "Teacher Beliefs Inventory for Strategy Instruction (TBISI)" presented by Moon, Lan and Oxford (2003) at the Annual Meeting of Washington Area Teachers of English to Speakers of Other Language in 2003, which was revised by Oxford in 2004 to measure the student teachers' beliefs of learning and strategy instruction. Question item 1-3 related to the student teachers' views about their use of strategies in learning English. The results showed that $32 \%$ students were not sure whether they were good strategy users. $47 \%$ of the respondents didn't consider themselves successful language learners. $34 \%$ of the respondents were not sure whether they are good at monitoring. It might indicate that student teachers' self-efficacy in using strategies was quite low, and they might lack knowledge about strategies and strategy use.

Besides, the data analysis of the student teachers' general views of learning strategy and strategy instruction showed that the student teachers had positive views about benefits of strategies in language learning (see question item $5, \mathrm{M}=4.30, \mathrm{SD}=0.56$, item $6, \mathrm{M}=4.44, \mathrm{SD}=0.55$ ); and majority of the participants believed in the importance of providing strategy instruction in teacher training program; however, they were not very clear about the nature of language learning strategies (see question item $4, \mathrm{M}=3.39$, $\mathrm{SD}=0.65$; item $10, \mathrm{M}=3.10, \mathrm{SD}=0.82$ ). The data showed that it was necessary to provide strategy instruction for these student teachers.

Table 2: Student teachers' views about learning strategies and strategy instruction

\begin{tabular}{|c|c|c|}
\hline Question Items & Mean & $\begin{array}{l}\text { Standard } \\
\text { deviation }\end{array}$ \\
\hline 1. When I was a language learner, I was a good user of strategies. & 3.60 & 0.65 \\
\hline 2. I consider myself a successful language learner. & 3.26 & 0.70 \\
\hline $\begin{array}{l}\text { 3. I have been able to plan, organize, evaluate and monitor my own } \\
\text { language learning. }\end{array}$ & 3.44 & 0.70 \\
\hline 4. I understand what language learning strategies are. & 3.39 & 0.65 \\
\hline $\begin{array}{l}\text { 5. Using strategies will make learning a second/ foreign language more } \\
\text { effective. }\end{array}$ & 4.30 & 0.56 \\
\hline $\begin{array}{l}\text { 6. Knowing how to learn more efficiently is important for language } \\
\text { learners. }\end{array}$ & 4.44 & 0.55 \\
\hline 7. A strategy is a tool, plan, or method used for accomplishing a task. & 3.97 & 0.76 \\
\hline 8. I can explain why strategy instruction is important. & 3.66 & 0.77 \\
\hline $\begin{array}{l}\text { 9. I feel that students don't have enough time to learn things other than } \\
\text { focused content knowledge. }\end{array}$ & 2.74 & 1.17 \\
\hline 10. The use of strategies should be evaluated as part of any test. & 3.10 & 0.82 \\
\hline $\begin{array}{l}\text { 11. Workshops or teacher training courses on strategy instruction will be } \\
\text { very helpful for me to actually implement strategy instruction. }\end{array}$ & 3.91 & 0.57 \\
\hline
\end{tabular}

Based on the above analysis results, this study attempts to apply SRL as a framework to develop a language learning strategy training program to enhance student teachers' motivation in language learning, to increase their awareness of strategy use, and to 
develop their knowledge and applications about language learning strategies and strategy instruction.

\section{Self-regulated learning and strategy instruction}

SRL, a multidimensional construct that involves cognitive, metacognitive, motivational, and social aspects of learning, has been theoretically well established. SRL has been widely studied from different theoretical perspectives (Zimmerman, 1989). Two metaanalysis studies (Dignath, Buettner, \& Langfeldt, 2008; Hattie, Biggs, \& Purdie, 1996) showed that SRL from social cognitive learning perspective provides a more comprehensive and practical approach for strategy instruction. The following is the theoretical basis of the study.

\subsection{A cyclic model of SRL}

Social cognitive learning views SRL as an interaction between personal, behavioural and environmental influences (Bandura, 1986). Personal factor refers to beliefs and attitudes learners have in a certain learning situation, such as, self-efficacy, i.e. the degree of confidence one possesses in reaching target learning goals in a given learning situation (Bandura, 1986); behavioral factor means responses or reactions students make in a given learning situation and it consists of three subfunctions of SRL, i.e., self-observation, selfevaluation and self-judgment; environmental factors, which are external as apposed to internal control of personal factors, such as, curriculum modules and materials, the role of teachers, parents, and peers during the learning process (Zimmerman, 2000).

With regard to the issue on how the self-regulation processes are structurally and systematically interrelated with each other, Zimmerman (2000) proposes a cyclic model of SRL to categorize self-regulatory processes and personal beliefs into three phases, namely, forethought, performance, and self-reflection phase. During the forethought phase, self-regulated learners form a full picture of the task in terms of situational factors, i.e., clarifying a task, setting goals, and planning specific strategies, and personal factors, i.e., setting up motivational beliefs about the task, such as, self-efficacy beliefs, namely, the perceived capability on finishing the task and self-expected outcomes. The second is performance phase that includes self-control and self-observation. Self-control refers to carrying out the strategies and tactics specified in the first phase by using self-control methods, such as, attention-focusing, self-instruction, and task strategies. Selfobservation means self-recording events to control learning behavior. The last phase is self-reflection which includes self-judgment and self-reaction during which students selfevaluate their performance against their prior performance or external standards set by others, and then reconstruct new information and make adaptive strategy changes toward their learning goals. 


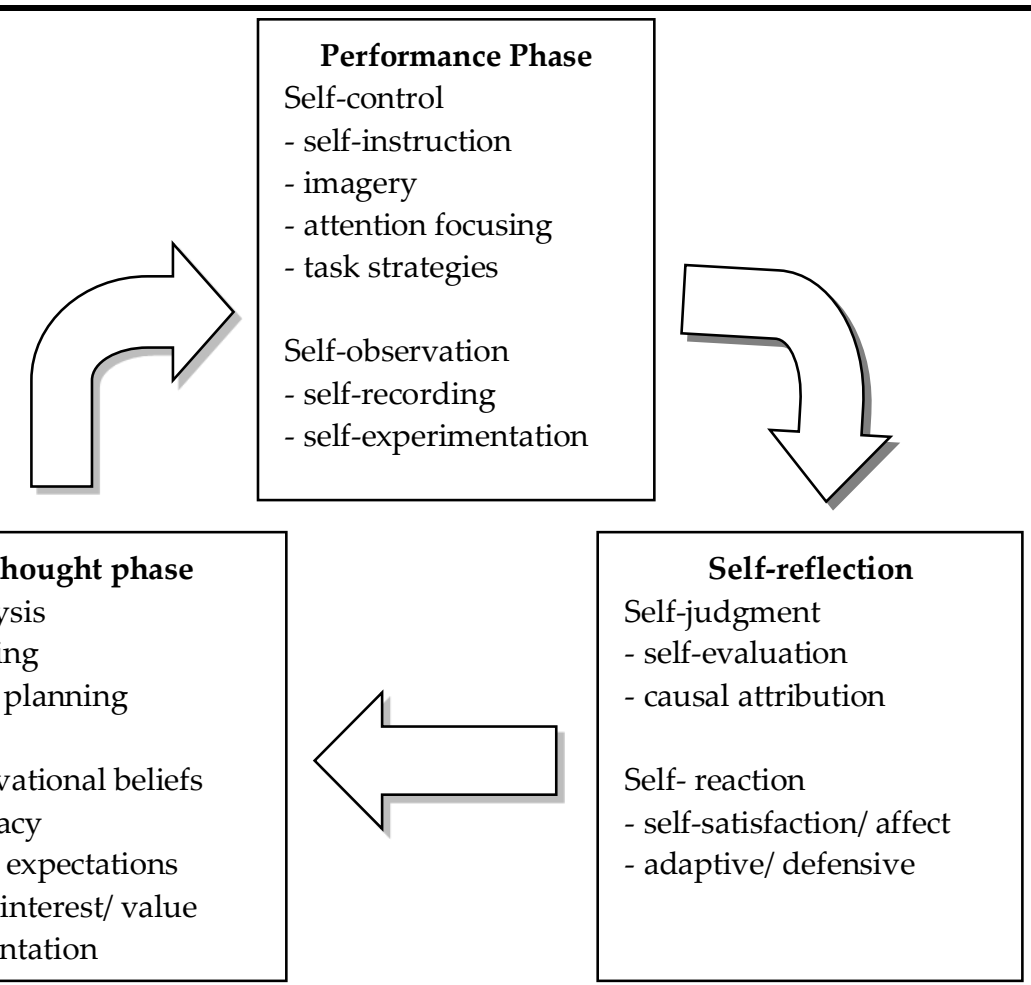

Figure 1: Phases and subprocesses of Self-Regulated Learning (SRL) (From "Attaining self-regulation: a social cognitive perspective," by B.J. Zimmerman (2000). In Boekaerts, M., Pintrich, P. R., and Zeidner, M. (Eds). Handbook of self- regulation. Academic Press.p.16)

\subsection{Self-regulatory language learning strategies}

The most frequently quoted definition of learning strategy is "behaviours and thoughts that a learner engages in during learning and that are intended to influence the learner's encoding process" by Weinstein and Mayer (1986, p. 315). Self-regulation involves all the learning strategies, the emphasis is on learners' self-initiation, that is, learners' own strategic efforts to manage their own learning process (Zimmerman, 2000). Therefore, there are two important components of SRL, namely, skill, i.e., learning strategies, and will, i.e., the motivation to use strategies (Pintrich, 2004). Zimmerman (1989) clarified that in order to identify students' strategies or actions to be self-regulated, one must know their academic goals and their perceptions of efficacy. Therefore, self-regulated language learning strategies refer to all the language learning strategies involved in the selfregulated learning process, and students who are self-regulated use specified cognitive, motivational, and behavioural strategies to achieve academic goals on the basis of their self-efficacy, namely, perceptions of their capabilities in performing a skill or a task. cognitive strategies related to the language learning skills and knowledge, metacognitive strategies function as executive control to observe, monitor and evaluate the use of cognitive learning strategies; motivational strategies used to control one's effort; behavioural strategies to construct both physical and social learning environment and setting to facilitate one's learning. 

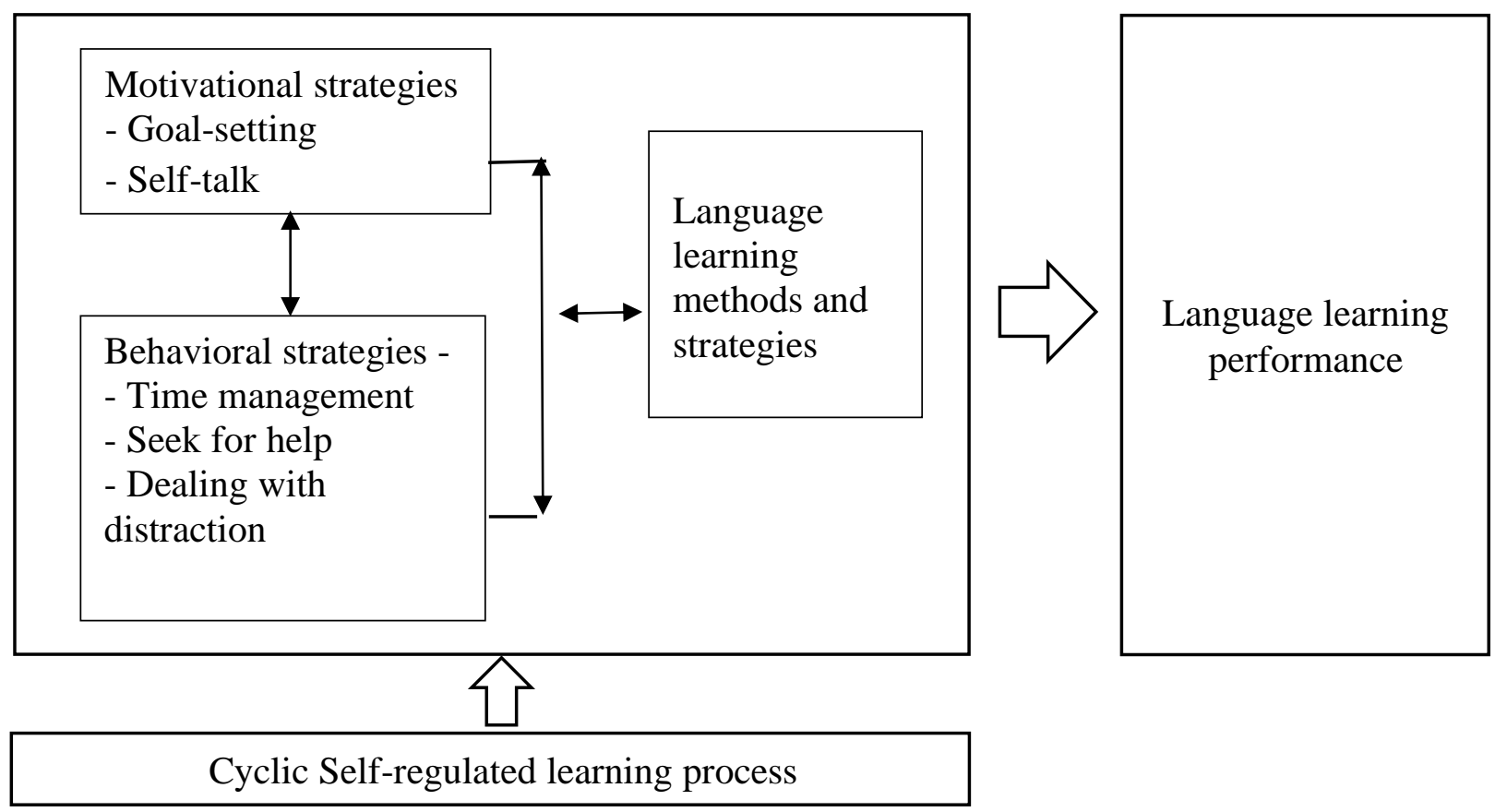

Figure 2. The relationship between SRL components

In addition, motivational aspects are identified as strategies learners use to manage their emotions, such as coping with tests or performance anxiety, or maintaining motivation. It is evident that the effective use of cognitive learning strategies occurs along with the other two aspects, that is, motivation and metacognition (Weinstein et al., 2005).

Based on the components of SRL (Zimmerman, 2000) and the framework of selfmanagement proposed by Dembo (2004), figure 2 is useful for understanding how selfregulated language learning occur in language learning. All the components of selfregulated learning may interact with each other.

\section{SRL instruction in an online learning environment}

Researchers developed different approaches to foster learners' self-regulated learning strategy development in a online learning environment. Winter, Greene and Costich (2008) proposed three ways to support SRL development, namely support tools, conceptual support and metacognitive support. Support tools allow learners to use online learning resources to monitor and control their learning processes; conceptual support refers to the online learning aids or guides to help learners understand the learning content; metacognitive support refers to the tools that can guide learners to reflect on the tasks and evaluate learning process. Blended learning environment could combine the benefits of traditional face-to-face classroom strategy instruction with those of online learning environment to foster learners' initiatives in learning, facilitate their learning process and support learners' use of self-regulated learning strategies.

Models of SRL from the social cognitive perspective can be a useful framework for understanding learning success in the online learning context since it explains the 
interrelationships between motivational, cognitive, metacognitive and social factors of learning (Artino, 2007). Based on the social cognitive view of SRL, Dabbagh and Kitsantas (2005) identified several key SRL processes, namely, goal setting, self- monitoring, selfevaluating, task strategies, help seeking, and time planning and management, which can be supported by using different categories of online technological tools. For example, collaborative and communication tools are applied to facilitate student to student or student to instructor interactions through the use of asynchronous communication tool (e.g., virtual chat, white board tool) and synchronous communication tools (e.g., email, discussion forums, bulletin boards); content creation and delivery tools allow instructors to upload course syllabus, course content and assignments, and manage resources as well as enable learners in accessing course resources and readings and submitting assignments, such as using assignment feature in WebCT to post assignments and class activities.

\section{Teacher education and strategy instruction}

Implementing learning strategy instruction in teacher training programs has received less attention by educational practitioners (Hamman, 1998, Rubin et al, 2007). Hamman (1998) stated that one reason for educational practitioners' reluctance to implement strategy instruction may arise from the preservice preparation they received. Elen and Lowyck (1999) found that pre-service teachers were not aware of the mechanism of effective learning process and how teachers can facilitate the learning process. The recent studies done by Van Deur et al. (2016) found that the most frequently used strategies used by Australian pre-service teachers were note-taking, repetition, review, and reading strategies, while motivational, metacognitive and problem-solving strategies are lacking among the participants. Thus, all these research findings suggested a strong recommendation to include learning-strategy instruction as part of pre-service training programs.

With a focus on improving teachers' strategic awareness and knowledge of learning strategies and strategy instruction, some researchers developed strategy training programs to enhance teachers' awareness of SRL. In terms of language teaching, some researcher (e.g., Harris et al., 2001; Chamot et al., 1999) developed language learning strategy training programs to enrich the research findings on strategy instruction for teachers' professional growth.

\section{Design principles for strategy instruction in blended learning environment for pre- service teacher training}

The principles of training teachers in strategy instruction are similar to those steps or principles involved in learner training, that is, the nature of active learning (Rubin et al., 2007). Chamot, Barnhardt, El- Dinary and Robbins (1999) identified four steps for design of strategy instruction for learners. First, learners should be aware of the strategies they 
are using; second, teachers should present and demonstrate strategies to increase students' awareness about learning and thinking process; third, students should be provided with substantial practice opportunities to move from depend to independent strategy users; fourth, students should be able to evaluate the effectiveness of strategy use and transfer the use of strategies in a new learning situation. This study is aimed at applying the principles of SRL from Social Cognitive Learning (SCL) theory and theories of language learning strategies to develop student teachers' use of self-regulatory strategies as well as their knowledge about strategies and strategy instruction. The reciprocal influences between cognitive and motivational factors are particularly emphasized in the SRL theories. Hence, there are four main aspects of SRL from the SCL perspective addressed in the design of the instruction, that is, motivational, environmental, cognitive and metacognitive aspects of language learning. The principles related to the six components of SRL processes (i.e., goal-setting, emotional control, environmental regulation, strategic planning, self-monitoring, self-evaluation, and selfreflection) serve to guide the design of the SRLLS training program. With reference to the existing principles of strategy instruction, the following presents the strategy instructional design principles for promotion of SRL in pre-service teachers. The rationale for each principle is explained as follows:

1) Selecting initial strategies to teach: determine which strategies could help with specific current challenges that student teachers are facing and start with the strategies student teachers need most and the strategies that have the wider applications.

2) Provision of explicit instruction on task-based language learning strategies. Learners should acquire a variety of strategies that they can use to handle a learning task so that they can select strategies that they believe are effective in performing a task (Paris \& Paris, 2001).

3) Deliberate effort on enhancing and promoting learners' metacognitive awareness in planning, monitoring and evaluation of strategy use. Metacognition plays a key role in promoting learners' self-regulation in learning. Metacognitive awareness and metacognitive strategy use refer to the notion that strategies should be planned, monitored, self-evaluated and self-controlled (Pintrich, 2004). In this study, the cycle of SRL processes (i.e., goal setting and planning, self-monitoring, self-evaluation and self-reflection) was applied as a structural framework for implementing language learning strategies in order to promote student teachers' metacognitive awareness and strategy use.

4) Modelling of strategy use through think aloud method. Social modelling has been a primary means to convey self-regulated language learning strategies and to encourage student teachers to self-construct strategies. In the initial stage of strategy instruction, it is critical to provide student teachers with strategies through cognitive modelling, i.e., verbalization of mental processes, especially for those with a limited repertoire of strategies. 
5) Provision of guided practice for student teachers to practise language learning strategies and metacognitive strategies. As in learning other skills, student teachers need to practise self-regulatory strategies continuously to internalize strategy use and finally automatizing the strategy use in their learning. For each new strategy, it is important to provide student teacher with a number of clear examples and sufficient practice in each of the strategies or combination of strategies

6) Adequate opportunities for independent practice. Provide further opportunities for student teachers to set appropriate learning goals and their plans and encourage them to try out their chosen strategies.

7) Continuous feedback and scaffolding while student teachers learn the strategies. It is crucial to provide scaffolding and continuous feedback on strategy use and performance. This enhances student teachers' self-efficacy and motivates them to continue using the strategies (Schunk \& Ertmer, 2005).

8) Constant practice of self-reflection. Self-reflection is a critical element for developing student teachers' self-regulatory abilities (Schunk \& Ertmer, 2005). It is important to give student teachers opportunities to evaluate the effectiveness of strategy use and their learning performance. Besides, self-reflective practices enable student teachers to evaluate their progress toward learning goals (Schunk \& Ertmer, 2005). Provide student teachers with opportunities for reflection and build up their self-efficacy by providing concrete evidence of their progress.

9) Providing student teachers with explicit instruction about the nature of SRL and strategy instructional models. Educational practitioners' presentation and demonstration of SRL and self-regulated learning strategy use should increase student teachers' awareness of effective strategy use and strategy instruction implementation in classrooms.

10) Using online technological tools to facilitate student teachers' self-regulated language learning strategy development. Online technological tools should be well integrated with strategy instructional content to enable student teachers to use strategies, such as goal-setting, self-monitoring, self-evaluation and selfreflection strategies etc.

11) Optimizing strategy instructional design to systematically to combine online learning with face-to-face learning on strategy instruction. The online learning tasks, including reading required reading materials to understand the basic concepts and theoretical principles about SRL and learning strategies, watching short video lectures about modelling and introduction and explanation of learning strategies, doing a variety of self-tests and awareness raising activities etc. are closely related to the instructional content of the face-to-face tasks. Besides, online learning tasks necessities the face-to-face discussion about a given topic or task. 


\section{Program structure}

The program engages a blended learning approach, that is, a combination of online modules and on-site meetings with teachers. It consists of 10 online modules and 11 faceto-face units. The aim of this module is to raise student teachers' awareness of their strategy use and learning process and to assist them in acquiring self-regulatory strategies in language learning. The module consists of three sections. Section I is aimed at providing theoretical foundations about self-regulated learning. It consists of the four sections, that is, the concepts of SRL and the purpose of the course are also introduced to the student teachers.

Section II focuses on explicit instruction in the selected motivational strategies including goal-setting, self-talk strategies etc.; section III instructs the student teachers about the environmental strategies including time management and environmental structuring etc; section IV focuses on the development of self-regulatory strategies in terms of vocabulary, pronunciation, grammar, listening, speaking, reading, and writing. Student teachers work on the online modules on the Blackboard learning platform. Modules are successively opened for access on date scheduled in advance. Table 1 presents the structure of the program.

Table 3: The structure of the program

\begin{tabular}{|c|c|c|c|}
\hline & Modules & Online sections & $\begin{array}{l}\text { Face-to-face } \\
\text { sections }\end{array}$ \\
\hline \multirow{3}{*}{$\begin{array}{l}\text { Section I. } \\
\text { Foundations of } \\
\text { SRLL }\end{array}$} & Module 1 & What is academic self-regulation? & Group discussion \\
\hline & Module 2 & $\begin{array}{l}\text { Why it is important for English teachers to } \\
\text { acquire self-regulation in learning? }\end{array}$ & Group discussion \\
\hline & Module 3 & $\begin{array}{l}\text { What is self-regulatory approach to language } \\
\text { learning strategy instruction }\end{array}$ & Group discussion \\
\hline \multirow{2}{*}{$\begin{array}{l}\text { Section II. } \\
\text { Motivational } \\
\text { strategies }\end{array}$} & Module 4 & How can I set an appropriate learning goal? & Group discussion \\
\hline & Module 5 & How can I manage my emotions and efforts? & $\begin{array}{l}\text { Modelling and } \\
\text { group discussion }\end{array}$ \\
\hline \multirow{3}{*}{$\begin{array}{l}\text { Section III. } \\
\text { Environmental } \\
\text { management } \\
\text { strategies }\end{array}$} & Module 6 & How can I manage my time? & $\begin{array}{l}\text { Modelling and } \\
\text { group discussion }\end{array}$ \\
\hline & Module 7 & How can I seek academic help? & $\begin{array}{l}\text { Modelling and } \\
\text { group discussion }\end{array}$ \\
\hline & Module 8 & How can I concentrate on my study? & $\begin{array}{l}\text { Modelling and } \\
\text { group discussion }\end{array}$ \\
\hline \multirow{5}{*}{$\begin{array}{l}\text { Section IV. } \\
\text { Self-regulatory } \\
\text { language learning } \\
\text { strategy } \\
\text { development }\end{array}$} & Module 9 & How can I improve my pronunciation? & $\begin{array}{l}\text { Modelling and } \\
\text { group discussion }\end{array}$ \\
\hline & Module 10 & How can I improve my vocabulary? & $\begin{array}{l}\text { Modelling and } \\
\text { group discussion }\end{array}$ \\
\hline & Module 11 & How can I improve my grammar? & $\begin{array}{l}\text { Modelling and } \\
\text { group discussion }\end{array}$ \\
\hline & Module 12 & How can I improve my listening? & $\begin{array}{l}\text { Modelling and } \\
\text { group discussion }\end{array}$ \\
\hline & Module 13 & How can I improve my speaking? & $\begin{array}{l}\text { Modelling and } \\
\text { group discussion }\end{array}$ \\
\hline
\end{tabular}




\begin{tabular}{|l|l|l|c|}
\hline \hline & Module 14 & How can I improve my reading? & $\begin{array}{c}\text { Modelling and } \\
\text { group discussion }\end{array}$ \\
\cline { 2 - 4 } & Module 15 & How can I improve my writing? & $\begin{array}{c}\text { Modelling and } \\
\text { group discussion }\end{array}$ \\
\hline $\begin{array}{l}\text { Section V. } \\
\text { Guidelines for } \\
\text { teaching self- } \\
\text { regulated } \\
\text { language learning } \\
\text { strategies in the } \\
\text { classroom }\end{array}$ & Module 16 & $\begin{array}{l}\text { How to conduct strategy instruction in } \\
\text { language classroom? }\end{array}$ & $\begin{array}{c}\text { Modelling and } \\
\text { group discussion }\end{array}$ \\
\cline { 2 - 5 } & Module 17 & $\begin{array}{l}\text { How can I evaluate students' use of language } \\
\text { learning strategies? }\end{array}$ & $\begin{array}{c}\text { Modelling and } \\
\text { group discussion }\end{array}$ \\
\hline & Module 18 & Review & \\
\hline
\end{tabular}

\section{Instructional components}

From SRL perspective, these instructional events are referred to the three cyclic phases of SRL, namely forethought phase, performance phase, and self-reflection phase. In strategy planning section, each learning strategy or combination of strategies are systematically sharpened with specific guided practices in both individual and group work. Various types of feedback are put to use: group feedback (written/verbal comments from the teacher or peers or the instructor). Each module consists of the five integrated stages, namely, introduction, assessing yourself, strategy planning, self-regulated practice, summary and self-reflection. The five components are in line with the three cyclic processes of SRL, that is, forethought, performance and reflection phases.

The first stage is for students to assess their strategy use performance. Several awareness raising activities are designed to enable them to be aware of the strong and weak points of their strategy use in the related learning tasks. In the second stage, the target strategies are introduced to the learners, and they are informed about the importance of each strategy and further guided to set a learning goal for the day's lesson. In the third stage, the strategies are modelled and explained to students, and each sub strategy is practised. In the fourth stage, learners are provided the opportunity to work out a task using the strategies they learned, or their self-constructed strategies to expand their language learning knowledge and skills; besides, it is important for teachers to provide feedback on the effectiveness of strategy use during the process. Finally, students are asked to reflect on their use of learning strategies and strategy instructional process and write learning logs.

\section{Conclusion}

This study attempted to design a self-regulated strategy training program in a blended learning environment for pre-service teachers, which may yield a small body of results to contribute to the research effort to enhance pre-service teachers' knowledge and practice of language learning strategies and strategy instruction. First, in line with the current research trends on emphasizing both cognitive and motivational concerns in 
language learning strategy instruction, the study has shown that the cyclic SRL processes has potentials to be a useful framework for the implementation of language learning strategy instruction involving explicit teaching of various cognitive, metacognitive, motivational strategies and behavioural strategies. Second, the study provides an experiential and active instructional approach to fulfil the student teachers' learning needs in enhancing both their strategic awareness and their knowledge and application of self-regulated language learning strategies and strategy instruction. Third, combing the potential benefits of online technological tools, blended learning environment may provide a better alternative solution to conduct strategy instruction in a more effective and efficient way.

\section{Conflicts of interest statement}

The authors declare that they have NO conflicts of interest in publication. They confirm that this work is original and has not been published elsewhere, nor is it currently under consideration for publication elsewhere.

\section{Acknowledgements}

The researchers would like to thank Shaanxi Normal University for funding the research under the innovation project "classroom teaching reform in Shaanxi Normal University" (19KT-JG41).

\section{About the authors}

Aminah Ma Ping is currently working as a lecturer at the school of foreign languages, Shaanxi Normal University, Xi'an city, China. She completed her doctoral study at Faculty of Education, University of Malaya. Her research interests are self-regulated learning, teacher education, and technology supported language teaching and learning. Qiao Hong is a lecturer at Xinjiang teacher's College. Her main research interests are curriculum and teaching theory, English teacher education.

\section{References}

Artino A. R. Jr, 2007. Self-regulated learning in online education: a review of the empirical literature. Retrieved from http://www.itdl.org/Journal/Jun 07/article01.htm.

Bandura A, 1986. Social foundations of though and action: A social cognitive theory, NJ, Prentice-Hall.

Bellhauser H, Lösch T, Winter C, Schmitz B, 2016. Applying a web-based training to foster self-regulated learning - Effects of an intervention for large numbers of participants. Internet and Higher Education 31: 87-100.

Butler D. L, 1998. The strategic content learning approach to promoting self-regulated learning: A report of three studies. Journal of Educational Psychology 90(4):682697. 
Chamot A. U, Barnhardt S, El- Dinary P. B, Robbins J, 1999. The learning strategies handbook, New York, NY, Addison Wesley Longman.

Dabbagh N, Kitsantas A, 2005. Using web- based pedagogical tools as scaffolds for selfregulated learning. Instructional Science 33:513- 540. Retrieved from http://www.springerlink.com/content/u400646752g2t021/

Dembo H. Myron, 2004. Motivation and learning strategies for college success: A selfmanagement approach. London: Lawrence Erlbaum Associates Publishers.

Dignath C, Buettner G, Langfeldt H.P 2008. How can primary school students learn selfregulated learning strategies most effectively? A meta-analysis on self- regulation training program. Educational Research Review 3: 101-129.

Du Xiaomei, Jiao Yancun, Zhen Liwang, 2011. Investigating teaching strategies among senior highschool teachers. Journal of He Bei Normal University $13: 2$

Elen J, Lowyck J, 1999. Metacognitive instructional knowledge: cognitive mediation and instructional design. Journal of Structural Learning and Intelligent System 13 : 145-169.

Harris V, Gaspar A, Jones B, Ingvarsdotttir, Neuburg R, Palos I Schindler I, 2001. Helping learners learn: Exploring strategy instruction in language classrooms across Europe C Graz, Austria: European Centre for Modern Languages.

Hattie J, Biggs J, Purdie N, 1996. Effects of learning skills interventions on student learning: a Meta-analysis. Review of Educational Research 66:2, 99-136.

Hamman D. 1998. Preservice teachers' value for learning-strategy instruction. The Journal of Experimental Education 66(3): 209-221.

$\mathrm{Hu}$ H. 2007. Effects of self-regulated learning strategy training on learners' achievement, motivation and strategy use in a web-enhanced instructional environment. (Doctoral dissertation). Retrieved from http://etd.lib.fsu.edu/theses/available/etd11132007-170117/unrestricted/hu dissertation final.pdf.

Moon K, Lan R. L, Oxford, R. L, 2003. Using the teacher beliefs inventory for strategy instruction. Paper presented at the Annual Meeting of Washington Area Teachers of English to Speakers of Other Languages (WATESOL), Washington D.C.

Paris S. G, Paris A. H, 2001. Classroom applications of research on self-regulated learning. Educational Psychologist 36(2): 89-101.

Pintrich P. R, (2004). A conceptual framework for assessing motivation and self-regulated learning in college students. Educational Psychology Review 16(4): 385-407.

Rubin J, Chamot A. U, Harris V, Anderson N. J, 2007. Intervening in the use of strategies. In A. D Cohen, E. Macaro. (Eds.) Language Learner Strategies. New York, NY, Oxford University Press, pp140-164.

Schunk D. H, Ertmer P. A, 2005. Self-regulation and academic learning: Self-efficacy enhancing interventions. In M. Boekaerts, P. R. Pintrich, M. Zeidner (Eds.), Handbook of self-regulation. San Diego, CA, Academic Press, pp. 631-649

Vieira K, 2003. Addressing constraints on autonomy in school contexts: lessons from working with teachers In Paltreyman D, R. C Smith (Eds): learner autonomy across cultures: Language Education perspectives. Basingstoke: Palgrave Macmillian 
Van Deur P, Napier R, Lawson M. J, 2016. Teachers' and pre-service teachers' knowledge about learning and teaching. Paper presented at the Annual Conference of the Australian Association for Research in Education, Melbourne, Australia.

Weinstein C. E, Husman J, Dierking D. R, 2005. Self- regulation interventions with a focus on learning strategies. In M Bockaerts, P. R Pintrich, M Zeidner (Eds.), Handbook of self- regulation . Academic Press, San Diego, CA, pp.727-747.

Weinstein C. E, Mayer R. E, 1986. The teaching of learning strategies. Handbook of research on teaching 3: 315-327.

Winters F. I, Greene J. A, Costich C. M, 2008. Self-regulation of learning within computerbased learning environments: A critical analysis. Educational psychology review 20 (4): 420-444.

Zimmerman B. J, 1989. Models of self- regulated learning and academic achievement. In B. J. Zimmerman, D. H. Schunk (Eds.), Self- regulated learning and academic achievement: Theory, research, and practice. New York, NY, Springer-Verlag, pp $1-19$.

Zimmerman B. J, 2000. Attaining self- regulation: A social cognitive perspective. In M Boekaerts, P. R Pintrich, M Zeidner (Eds.), Handbook of self- regulation. San Diego, CA, Academic Press, pp. 13-39. 
Creative Commons licensing terms

Authors will retain the copyright of their published articles agreeing that a Creative Commons Attribution 4.0 International License (CC BY 4.0) terms will be applied to their work. Under the terms of this license, no permission is required from the author(s) or publisher for members of the community to copy, distribute, transmit or adapt the article content, providing a proper, prominent and unambiguous attribution to the authors in a manner that makes clear that the materials are being reused under permission of a Creative Commons License. Views, opinions, and conclusions expressed in this research article are views, opinions and conclusions of the author(s). Open Access Publishing Group and European Journal of English Language Teaching shall not be responsible or answerable for any loss, damage or liability caused in relation to/arising out of conflict of interests, copyright violations and inappropriate or inaccurate use of any kind content related or integrated on the research work. All the published works are meeting the Open Access Publishing requirements and can be freely accessed, shared, modified, distributed and used in educational, commercial and non-commercial purposes under a Creative Commons Attribution 4.0 International License (CC BY 4.0). 